\title{
Numerical Analysis of Crack Propagation Path Using an Advanced Element Cracking Method
}

\author{
Z. P. Zhong, S. Wan, ${ }^{1}$ and Z. W. Jiang \\ School of Transportation, Southeast University, Nanjing, China \\ 11.1anyu421@163.com
}

УДК 539.4

\section{Численный расчет траектории распространения трещины с помощью усовершенствованного метода моделирования процесса трещинообразо- вания}

\author{
3. П. Джонг, С. Ван ${ }^{1}$, 3. В. Джянг
}

Факультет транспортных коммуникаций, Южно-восточный университет, Нанджинг, Китай

Определение траектории трещчины является важным при прогнозировании непредвиденного разрушения или при оченке усталостной долговечности конструкционного материала. Предложен новый метод моделирования траектории локальной трещчины при нагружении смешанного типа с помощьью модели, основанной на методе конечных элементов. Элемент, моделирующий трещину, разбивают на два вдоль распространения трещчинь с использованием критерия максимальных касательных напряжений $\left(K_{I I}=0\right)$. Затем изменяется информация о номерах элемента и узла, поскольку метод трансфикиии исключает использование сингулярных элементов. Преимущества незначительного перестроения конечноэлементной сетки только в локальной зоне позволили исследовать с помощью предложенного метода три классические проблемы роста стационарной трещины, т.е. распространение краевой трещины в двухконсольной балке, моделирование трещинообразования в асфальтобетонных балках и трещзина в стандартном продольном соединении в газопроводе. Расчетный коэффициент интенсивности напряжений и траектория трещцины, спрогнозированная с помощьью описанного метода, хорошо соответствуют теоретическим данным, представленным в литературных источниках. Рассмотрена оптимальная конструкция структуры, которой несвойственно быстрое разрушение.

Ключевые слова: конечноэлементный анализ, траектория трещины, элемент, моделирующий трещину, коэффициент интенсивности напряжений, разрушение смешанного типа.

Introduction. In engineering complex structures, the determination of the crack path is important to analyze the failure mode, and assess structure strength and residual life [1-3]. Different theoretical, numerical, and experimental methodologies have been developed to investigate the crack propagation problem $[4,5]$, among which, numerical simulation is widely used due to its simplicity and economy, including the meshless methods and finite element method (FEM) with remeshing [6-19]. Massless methods do not require crack propagation paths to coincide with the meshes. Recently, Belytschko et al. $[6,7]$ predicted the simple crack propagation with a high accuracy using the moving least-squares interpolation with the Galerkin method. The numerical manifold method (NMM) was first reported by Shi and Goodman to deal with rock joints and block [8, 9]. The displacement discontinuity across a crack surface is approximated by independent cover functions on different physical covers. Meanwhile the additional functions extracted from the asymptotic 
near tip field are incorporated into cover functions of singular physical covers to simulate the stress singularity around the crack tips. Stay et al. [10] and Chou et al. [11] applied the N.M. for crack propagation problems successfully. The extended finite element method (XFEM) $[12,13]$ is another technique to solve the crack propagation problem without the computational mesh, in which the discontinuous Heaviside function and the near-tip asymptotic functions through a partition of unity method are added to the FEM to account for crack. Besides, the generalized finite element method (GFEM) takes advantage of high-order terms or handbook functions of boundary value problems to tackle the crack problem $[14,15]$.

However, improvements of meshless methods should be done to dispose multiple cracks and large deformation crack propagation problems. In an actual situation, a real mesh discontinuity represents the crack [16], which can be effectively solved by finite element method with remeshing despite the complicated mesh generation. Many researchers have applied the finite-element method with remeshing algorithms to model crack propagation problems [17-19]. Shephard et al. [18] adopted remeshing the entire model in every step to realize crack propagation. However, a large number of state variables such as displacement, stress and strain need to be transferred from the old to the new mesh model in every step. Souiyah et al. [19] employed a local remeshing technique whereby only the region around the crack tip is modified, but the well-shaped elements can't be generated usually due to the existing mesh surrounding the region.

An advanced remeshing technique combined with a nodal relaxation is proposed to predict the crack growth. In order to avoid complete remeshing on the global region, we firstly calculate the direction vector of crack propagation at the crack tip based on the maximum circumference $\left(K_{\mathrm{II}}=0\right)$ criterion and the direction vector of the edge by taking the crack tip point as an initial point in the triangular element. Then, after determining the waiting crack element by vector cross product, the intersection point coordinates between crack direction and cracking boundary are also confirmed, and the unit is split. Finally, a new unit is added, and the node number and element number are modified. As the mesh division is only on the local region, the modifying grid data and the interpolation of displacement field are small. This method has such advantages as less modified area, easiness of programming, high reliability etc. In the end, the numerical model is verified by comparing the numerical results with the benchmark solutions and the laboratory test results.

1. Grid Generation Strategy. In simulation of crack growth in finite element modeling, the technique of mesh generation is very significant in dynamic crack propagation. Various publications focus on the automatic crack propagation using finite elements remeshing [5, 17-19]. Different from the traditional remeshing in finite modeling, the element cracking technique is developed in this work.

1. When the equivalent stress intensity factor (SIF) of crack satisfies fracture critical value, the crack is going to propagate along propagation direction within the element. The element where the crack propagation direction is located should be confirmed first. Then, search all elements around the crack tip node $A$, such as the cell $1,2,3,4,5,6$, and 7 (Fig. 1a).

The vector of propagation direction and vector setting point $A$ as the initial point are given as (Fig. 1b):

$$
\begin{array}{cc}
\boldsymbol{r}=(\cos \theta) \boldsymbol{i}+(\sin \theta) \boldsymbol{j}, & \boldsymbol{A B}=\left(x_{B}-x_{A}\right) \boldsymbol{i}+\left(y_{B}-y_{A}\right) \boldsymbol{j}, \\
\boldsymbol{A C}=\left(x_{C}-x_{A}\right) \boldsymbol{i}+\left(y_{C}-y_{A}\right) \boldsymbol{j}, & \ldots,
\end{array}
$$

where $\theta$ is the propagation direction angle, $x_{N}, y_{N}(N=A, B, \ldots)$ are longitudinal coordinate and transverse coordinate values, respectively, while $\boldsymbol{i}$ and $\boldsymbol{j}$ denote the unit vector in the $x$ and $y$ directions, respectively. 


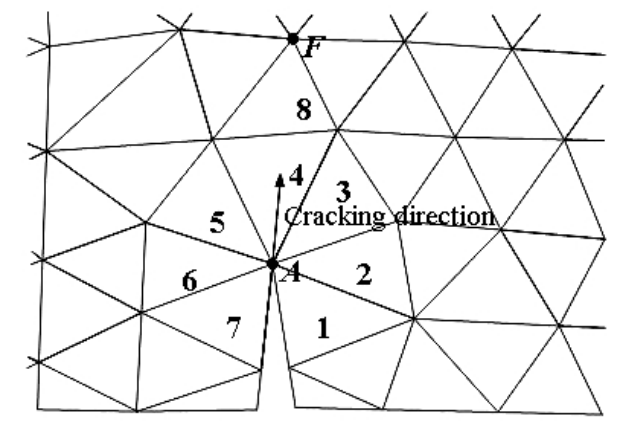

a

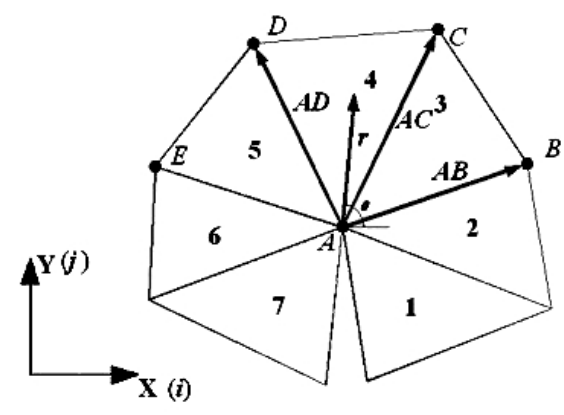

b

Fig. 1. Elements' remeshing: (a) the cracking direction; (b) the vector in rectangular coordinate.

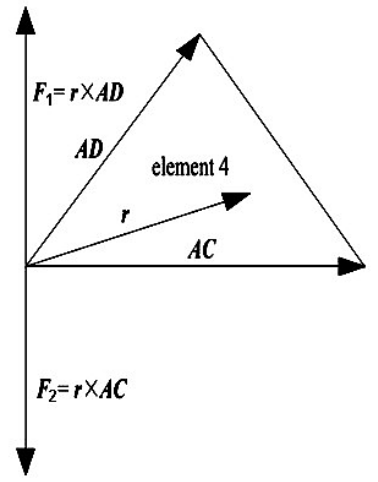

a

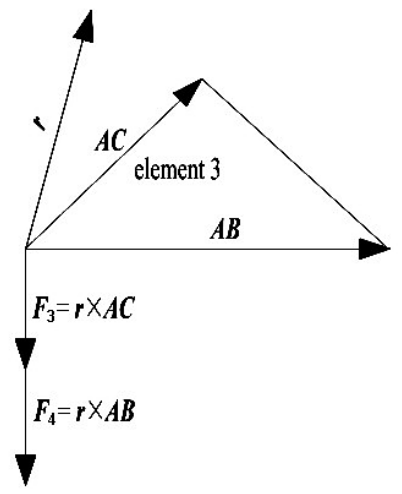

b

Fig. 2. Vector cross product: (a) in element 4; (b) in element 3.

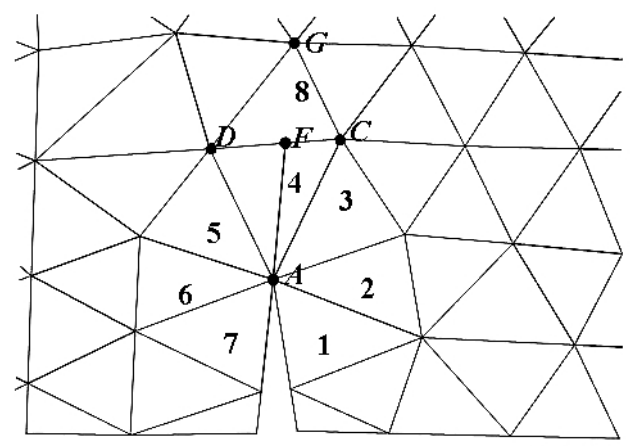

Fig. 3. Increment of a cracking node.

By appling vector cross direction of $\boldsymbol{r}$ and two edge vectors, when the vector cross direction is different, the element waiting crack is determined. For example, setting $\boldsymbol{F}_{1}=\boldsymbol{r} \times \boldsymbol{A D}$ and $\boldsymbol{F}_{2}=\boldsymbol{r} \times \boldsymbol{A C}$ in element 4 (Fig. 2a), $\boldsymbol{F}_{3}=\boldsymbol{r} \times \boldsymbol{A C}$ and $\boldsymbol{F}_{4}=\boldsymbol{r} \times \boldsymbol{A B}$ in element 3 (Fig. 2b), if $\boldsymbol{F}_{1} \cdot \boldsymbol{F}_{2}<0$ in element 4, and $\boldsymbol{F}_{3} \cdot \boldsymbol{F}_{4}>0$ in element 3 , element 4 is the cracking element.

2. Considering the increment of crack propagation being the size of the element, the coordinates of a new crack vertex $F$ can be found by intersection operations as follows (Fig. 3): 


$$
\cos \theta=\frac{x_{F}-x_{A}}{\sqrt{\left(x_{F}-x_{A}\right)^{2}+\left(y_{F}-y_{A}\right)^{2}}}, \quad \frac{x_{C}-x_{F}}{x_{C}-x_{D}}=\frac{y_{C}-y_{F}}{y_{C}-y_{D}} .
$$

Via Eq. (1), the coordinate values $x_{F}$ and $y_{F}$ can be obtained.

3. After the intersection point $F$ determined, then element 4 is split, and node $A$ is separated into two nodes. Update and output the data of the modified finite element grid, and enter into the next calculation step.

To avoid the calculated crack propagation path to deviate from the true experiment path, the crack propagation length should be limited to one or two elements every time, and the load step magnitude should be chosen accordingly. More details of operation are discussed in [20]. During the process of crack growth, the singular element such as the shortest and the longest edges $h / H$ less than a given value $\varepsilon$ may be raised, thus affecting computational accuracy. A node combination method is handled to deal with the above problem (Fig. 4).
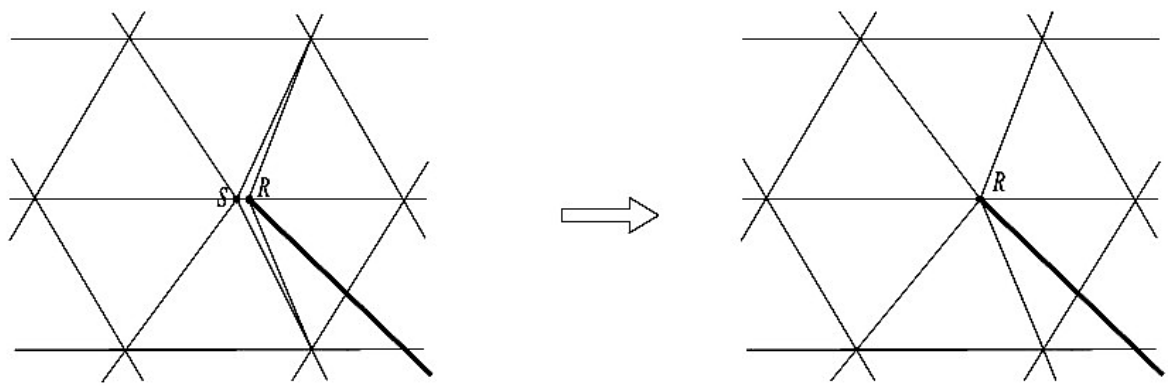

Fig. 4. Node elimination, node $S$ is eliminated, and ill-elements are removed.

2. Crack Propagation Theory. Within a framework of the linear elastic fracture mechanics, the fracture criterion for crack growth prediction is very important. The fracture criterion based on the stress intensity factor (SIF) is selected as

$$
K_{e f f}>K_{\mathrm{I} c},
$$

where

$$
K_{e f f}=K_{\mathrm{I}}\left(\cos \frac{\theta}{2}\right)^{3}-\frac{3}{2} K_{\mathrm{II}} \cos \frac{\theta}{2} \sin \theta .
$$

Here $K_{\text {eff }}$ is the effective stress intensity factor, in which $K_{\mathrm{I}}$ and $K_{\mathrm{II}}$ are the SIFs related to mode I and mode II loading configurations, respectively, and $\theta$ is the crack initiation angle. The value of $K_{\mathrm{I} c}$ is mode I critical fracture toughness determined by experimental test.

Prediction of deflection angles $\theta$ for cracks under mixed-mode loading presents a further challenge. There are various criteria such as the maximal strain energy release rate [21], the criterion of maximal normal stress [22], the strain energy density fracture criterion [23]. Based on the maximum circumferential stress theory, the angle of crack propagation $\theta$ was computed by

$$
\theta=2 \arctan \frac{1}{4}\left(K_{\mathrm{I}} / K_{\mathrm{II}} \pm \sqrt{\left(K_{\mathrm{I}} / K_{\mathrm{II}}\right)^{2}+8}\right) .
$$

In Eqs. (2) and (3), the mode I and mode II stress intensity factors $K_{\mathrm{I}}$ and $K_{\mathrm{II}}$ should be computed by interaction integral derived from the $J$-integral by Rice [24]. For 


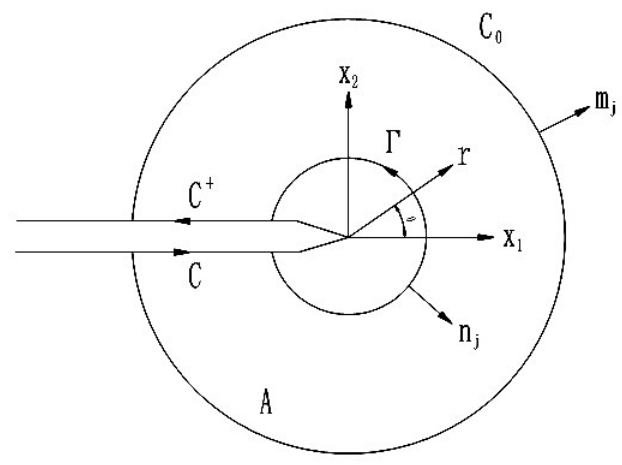

Fig. 5. Conventions at crack tip. Domain $A$ is enclosed by $\Gamma, C^{+}, C^{-}$, and $C_{0}$. Unit normal $m_{j}=-n_{j}$ on $\Gamma$.

simplicity, the coordinates are located at the crack tip with the $x_{1}$-axis parallel to the crack faces, as shown in Fig. 5.

The standard $J$-integral is

$$
J=\lim _{\Gamma \rightarrow 0} \int_{\Gamma}\left(W \delta_{1 j}-\sigma_{i j} u_{i, 1}\right) n_{j} d \Gamma,
$$

where $W$ is the strain energy density, $W=\sigma_{i j} \varepsilon_{i j} / 2$, the symbol $\delta_{1 j}$ is Kronecker delta, and $n_{j}$ is the unit outward normal vector to the contour $\Gamma$. Let $\left(\sigma_{i j}^{(1)}, \varepsilon_{i j}^{(1)}, u_{i}^{(1)}\right)$ be the present state and $\left(\sigma_{i j}^{(2)}, \varepsilon_{i j}^{(2)}, u_{i}^{(2)}\right)$ be an auxiliary state. The $J$-integral for the sum of the two states is

$$
J^{(1+2)}=\lim _{\Gamma \rightarrow 0} \int_{\Gamma}\left[\frac{1}{2}\left(\sigma_{i j}^{(1)}+\sigma_{i j}^{(2)}\right)\left(\varepsilon_{i j}^{(1)}+\varepsilon_{i j}^{(2)}\right) \delta_{1 j}-\left(\sigma_{i j}^{(1)}+\sigma_{i j}^{(2)}\right) \frac{\partial\left(u_{i}^{(1)}+u_{i}^{(2)}\right)}{\partial x_{1}}\right] n_{j} d \Gamma .
$$

By expanding and re-organizing terms,

$$
J^{(1+2)}=J^{(1)}+J^{(2)}+I^{(1,2)},
$$

where $I^{(1+2)}$ is called the interaction integral for states 1 and 2,

$$
I^{(1,2)}=\int_{\Gamma}\left[W^{(1,2)} \delta_{1 j}-\sigma_{i j}^{(1)} \frac{\partial\left(u_{i}^{(2)}\right)}{\partial x_{1}}-\sigma_{i j}^{(2)} \frac{\partial\left(u_{i}^{(1)}\right)}{\partial x_{1}}\right] n_{j} d \Gamma,
$$

where $W^{(1,2)}$ is the interaction strain energy, $W^{(1,2)}=\sigma_{i j}^{(1)} \varepsilon_{i j}^{(2)}=\sigma_{i j}^{(2)} \varepsilon_{i j}^{(1)}$.

For isotropic materials, the relationship between the $J$-integral and the SIF is

$$
J=\frac{\left(K_{\mathrm{I}}^{2}+K_{\mathrm{II}}^{2}\right)}{E^{*}},
$$

where $E$ is the Young modulus, $v$ is Poisson's ratio, 


$$
E^{*}=\left\{\begin{array}{lll}
E & \text { for } & \text { plane stress, } \\
E /\left(1-v^{2}\right) & \text { for } & \text { plane strain. }
\end{array}\right.
$$

Similarly, the interaction integral can be written as

$$
I^{(1,2)}=\frac{2\left(K_{\mathrm{I}}^{(1)} K_{\mathrm{I}}^{(2)}+K_{\mathrm{II}}^{(1)} K_{\mathrm{II}}^{(2)}\right)}{E^{*}} .
$$

By assigning $K_{\mathrm{I}}^{(2)}=1, K_{\mathrm{II}}^{(2)}=0$ and $K_{\mathrm{I}}^{(2)}=0, K_{\mathrm{II}}^{(2)}=1$, mode I and mode II SIFs can be decoupled. The interaction integral $I^{(1,2)}$ is not suitable for FEM and should be translated into the equivalent domain integral form. More detail can be seen in [13].

3. Numerical Analysis and Validation. In order to evaluate the accuracy of the present approach, three examples are applied. First, the result of a steel double cantilever beam (DCB) specimen simulated by FEM is compared with that produced by an analytical method. Then, attention is focused on the propagation of mode I crack in an asphalt concrete beam and crack growth from a fillet.

3.1. Edge Crack Propagation in Double Cantilever Beam. The beam has an initial crack length $a_{0}=100 \mathrm{~mm}$, the length $2 L=200 \mathrm{~mm}$, height $2 H=20 \mathrm{~mm}$. The mechanical properties of materials are chosen as steel for replication with $E=2 \cdot 10^{5} \mathrm{MPa}, v=0.3$, and $K_{\mathrm{I} c}=48.3 \mathrm{MPa} \sqrt{\mathrm{m}}$. Before the DCB achieves the critical fracture toughness, the computed values of the stress intensity factor are compared with the analytical solutions provided by [25], as shown in Fig. 6 . The present values of stress intensity factors are very close to the theoretical solutions and manifest a good agreement with the virtual crack closure technique (VCCT) [26] with the maximum percent differences of $1.8 \%$, which demonstrates the validity of the SIF computed via the interaction integral.

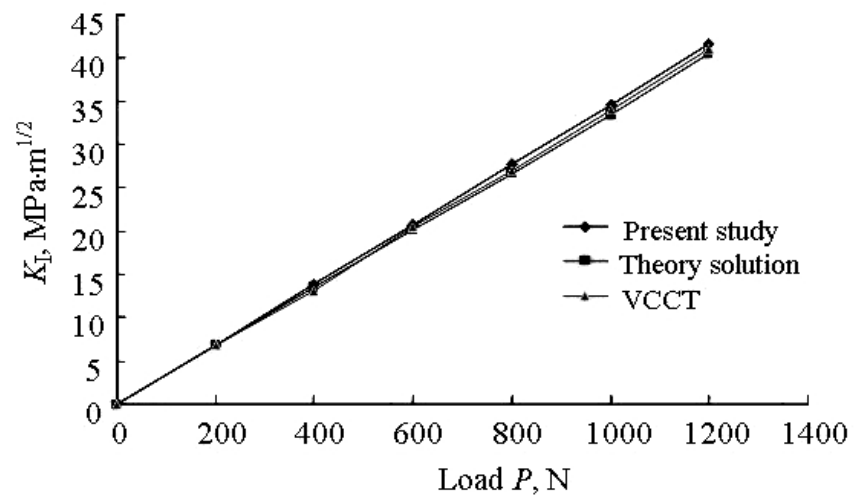

Fig. 6 Stress intensity factor values for DCB.

The load/deflection curve ( $P$ vs $\Delta$ ) is plotted in Fig. 7. It shows that the load $P$ increases nearly linearly with the increasing deflection $\Delta$ at first. The strain energy accumulates at the crack tip, and the SIF increases at this time. When the SIF exceeds the critical value, the crack starts to grow and the strain energy releases, then the load decreases. Therefore, the load in point $A$ is called critical load.

Figure 8 shows the crack propagation path with the initial crack offset $\delta=10 \mathrm{~mm}(\delta$ is the distance between the neutral axis and the crack), which is similar to the calculated results in [27]. 


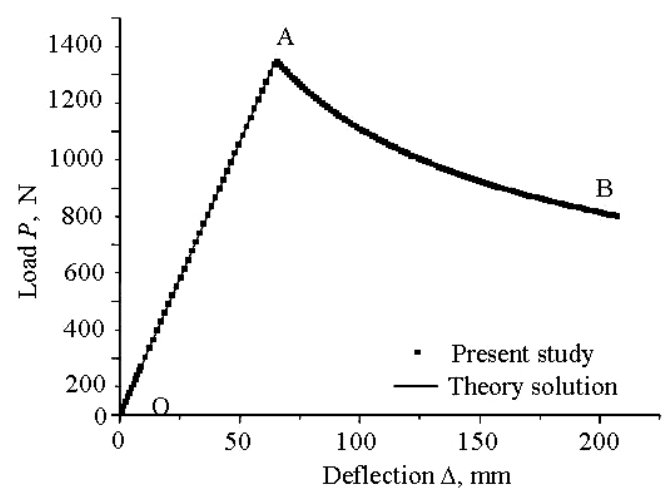

Fig. 7. Load/deflection curve for crack growth in DCB.

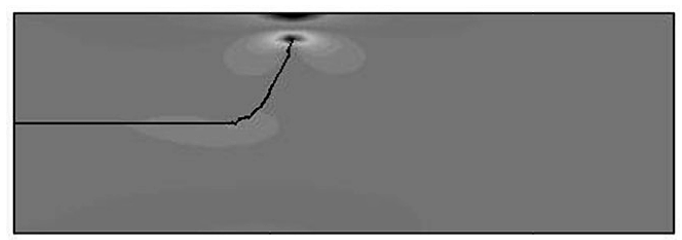

Fig. 8. The crack propagation path for DCB after limited steps of loading.

3.2. Three-Point Bend Specimen. Mode-I fracture characterization of concrete and rock materials adapting the notched three-point bend beam specimens has been researched widely. The test configuration of an asphalt concrete specimen under three-point bending is shown in Fig. 9. The span length of beam between the supports is $S=200 \mathrm{~mm}$, the beam height is $H=50 \mathrm{~mm}$ and the initial crack length $a_{0}=25 \mathrm{~mm}$ as illustrated in Fig. 10. The asphalt concrete properties $E=989 \mathrm{MPa}$ and $v=0.3$ were chosen for the specimen, in order to compare the numerical results with the experimental data in [28]. Figure 11a-b shows four steps of typical crack propagation. The predicted crack propagation seems to follow the mode I with evident tensile stress concentration at the crack tip. Figure 12 shows the crack propagation path by the experiment [28], which is consistent with the calculated one. The load-displacement curve is depicted in Fig. 13. The results agree well with the experiment when the load increases, and deviate when decreasing, which may be attributed to the linear elastic fracture mechanics. Therefore, a more complicated constitutive model should be introduced, such as plasticity and viscoelasticity.

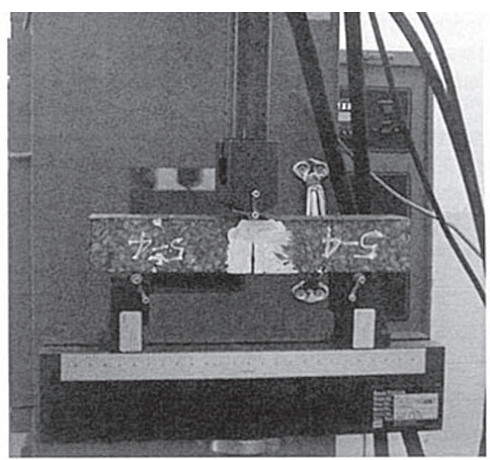

Fig. 9

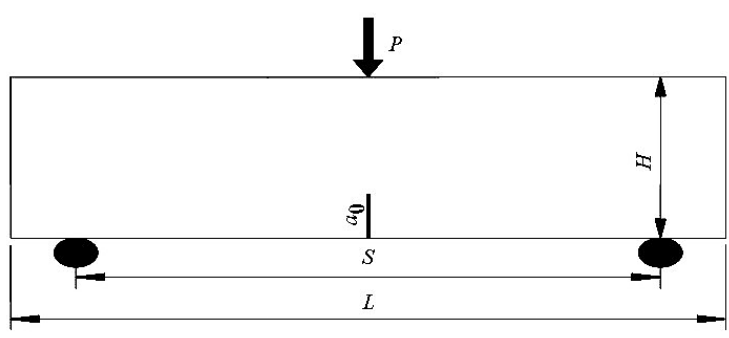

Fig. 10

Fig. 9. Test configuration of three-point bending beam for mode I fracture.

Fig. 10. Three-point bending geometry dimensions. 


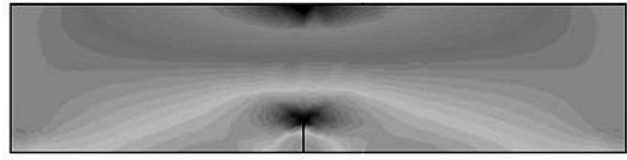

a

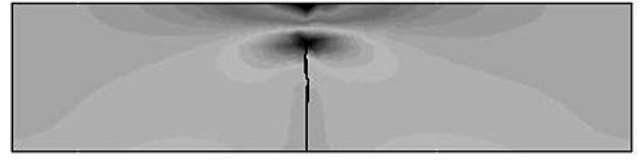

b

Fig. 11. Crack growth process in three-point bending beams.

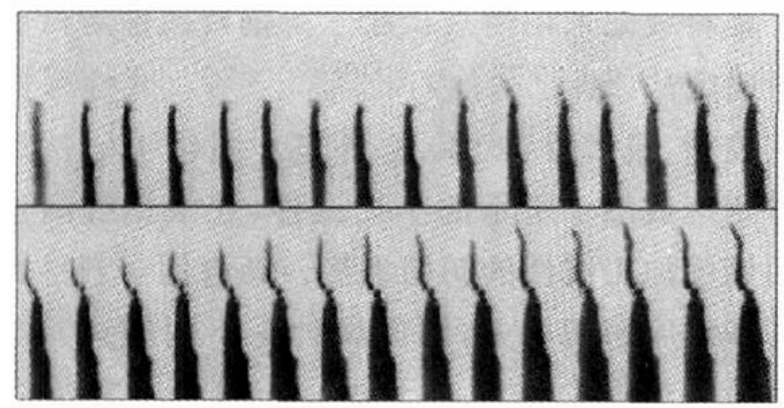

Fig. 12. Process of crack propagation of specimen in [28].

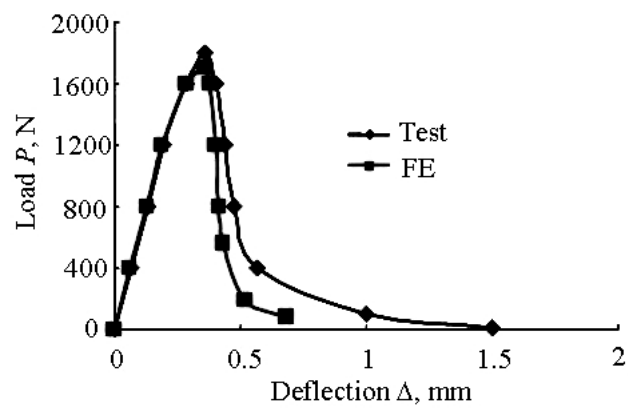

Fig. 13

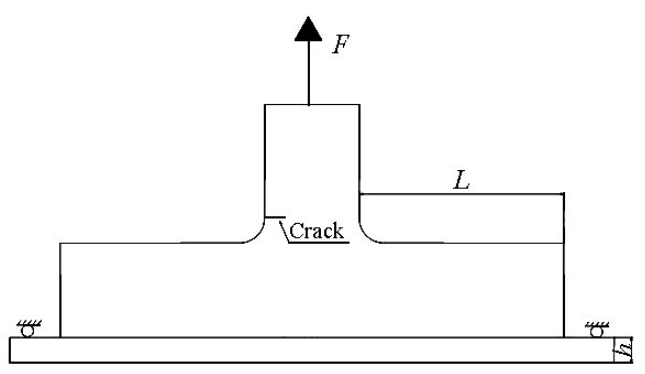

Fig. 14

Fig. 13. Load-displacement curve of three-point bended beam.

Fig. 14. Crack growth from a fillet.

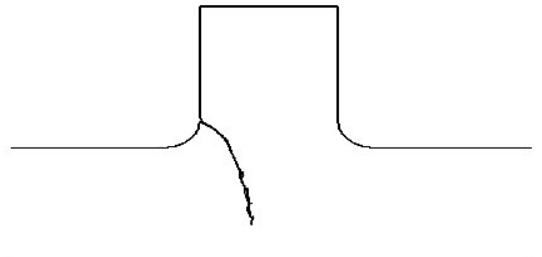

a

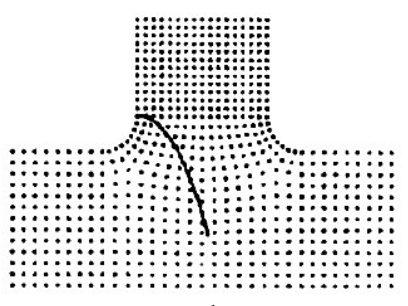

b

Fig. 15. Comparison of crack paths calculated via the proposed FEA crack propagation method (a) and calculated by [30] (b) for low values of $h(h=10 \mathrm{~mm})$.

3.3. Crack Growth from a Fillet. This last example, performed experimentally by Sumi [29], shows the growth of a crack from a fillet in a structural member (Fig. 14). The results presented here are for a simplified model, which only considers the bottom I-beam for a very thick beam and a thin beam $h$, and various length $L$ values. The mechanical properties of materials are assumed to be linear elastic under plane-strain conditions with 


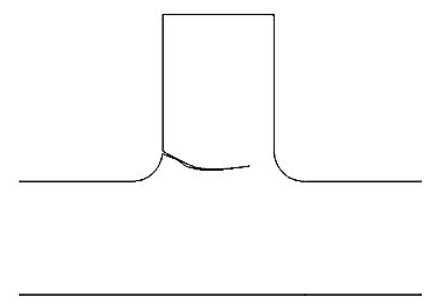

a

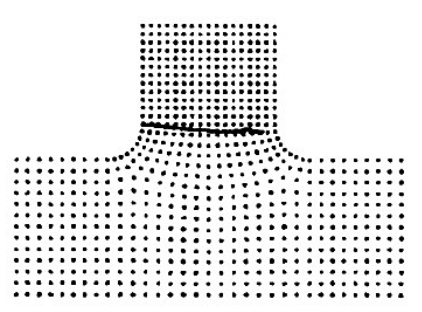

b

Fig. 16. Comparison of crack paths calculated via the proposed FEA crack propagation method (a) and calculated by [30] (b) for high values of $h(h=30 \mathrm{~mm})$.

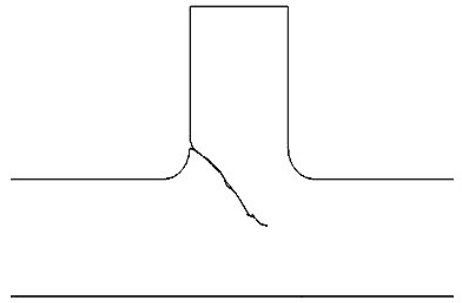

a

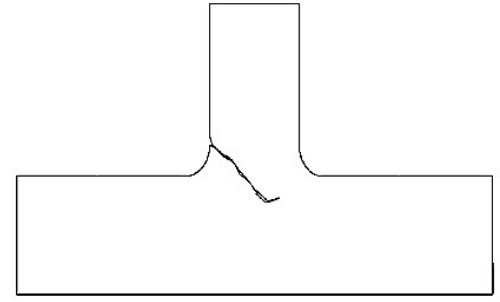

b

Fig. 17. Crack paths for various length $L$ values: (a) $L=362.5 \mathrm{~mm}$; (b) $L=162.5 \mathrm{~mm}$.

$E=10 \mathrm{MPa}$ and $v=0.3$. The applied load is $F=1 \mathrm{~N}$, the fillet radius is $20 \mathrm{~mm}$, and the initial crack length is $a_{0}=5 \mathrm{~mm}$.

Crack paths obtained by the element-free Galerkin method [30] and the results by the proposed crack propagation technique are compared for a part containing a flexible I-beam. Figures 15 and 16 show the excellent correlation of the two techniques. Figure 16 depicts that the crack turns sharply downwards and propagates towards the structure bottom, in case of low values of $h$. In contrast, when the structure is supported by a rigid I-beam, the crack will propagate horizontally towards the opposite fillet, as shown in Fig. 16.

The crack paths for various lengths $L$ are shown in Fig. 17. In case of high values of $L$, the crack propagates to the bottom of the structure at some angle (Fig. 17a), while in case of small values of $L$, it first propagates to the bottom, then goes upward to the other side of structure (Fig. 17b).

Conclusions. In this paper, a new element cracking technique is used to simulate the crack propagation by the finite element model. With only local remeshing and step-by-step node relaxation in the crack zone, this technique can be applied to complex industrial structures without complicated computation. To validate this technique, three examples are examined by displaying the stress redistribution and consternation at the crack tip during crack propagation. The stress intensity factors predicted by the interaction integral and the cracking direction are in good agreement with the exact solutions and experimental observations. The path of crack growth affects the condition of load and the geometric parameter of structure. Hence, it is crucial to decrease the amplitude of SIFs and change the failure model to make sure the crack extension occurs along the predetermined path by proper designing. Further work will focus on simulating the interface crack propagation between different materials using this method.

Acknowledgments. This research was supported by the National Basic Research Program of China (2012CB026200); National Natural Science Foundation of China (Grant No. 50978055). The author is also grateful to Beijing Fegensoft Corporation for helpful remarks and assistance. 
Р езюме

Визначення траєкторії тріщини $є$ важливим при прогнозуванні непередбачуваного руйнування або при оцінці довговічності від утомленості конструкційного матеріалу. Запропоновано новий метод моделювання траєкторії локальної тріщини під час навантаження змішаного типу за допомогою моделі, що базується на методі скінченних елементів. Елемент, що моделює тріщину, розбивають на два вздовж поширення тріщини з використанням критерію максимальних дотичних напружень $\left(K_{\mathrm{II}}=0\right)$. Далі змінюється інформація щодо номерів елемента і вузла, оскільки метод трансфікції виключає використання сингулярних елементів. Переваги незначної перебудови скінченноелементної сітки тільки в локальній зоні дозволили за допомогою запропонованого методу дослідити три класичні проблеми росту стаціонарної тріщини: поширення краєвої тріщини в двоконсольній балці, моделювання тріщиноутворення в асфальтобетонних балках і тріщина в стандартному поздовжньому з'єднанні у газопроводі. Розрахунковий коефіцієнт інтенсивності напружень і траєкторія тріщини, спрогнозована за допомогою описаного методу, добре відповідають теоретичним даним, представленим у літературних джерелах. Розглянуто оптимальну конструкцію структури, якій невластиве швидке руйнування.

1. P. P. Camanho, C. G. Davila, and M. F. de Moura, "Numerical simulation of mixed-mode progressive delamination in composite materials," J. Compos. Mater., 37, 1415-1438 (2003).

2. D. Rozumek, C. T. Lachowicz, and E. Macha, "Analytical and numerical evaluation of stress intensity factor along crack paths in the cruciform specimens under out-ofphase cyclic loading," Eng. Fract. Mech., 77, 1808-1821 (2010).

3. J. Shi, D. Chopp, J. Lua, et al., "Abaqus implementation of extended finite element method using a level set representation for three-dimensional fatigue crack growth and life predictions," Eng. Fract. Mech., 77, 2840-2863 (2010).

4. H. Zhou, A. Mehmanparast, C. M. Davies, and K. M. Nikbin, "Evaluation of fracture mechanics parameters for bimaterial compact tension specimens," Mater. Res. Innov., 17, 318-322 (2013).

5. A. R. Shahani and M. R. Amini Fasakhodi, "Finite element analysis of dynamic crack propagation using remeshing technique," Mater. Design, 30, 1032-1041 (2009).

6. T. Belytschko, Y. Y. Lu, L. Gu, and M. Tabbara, "Element-free Galerkin methods for static and dynamic fracture," Int. J. Solids Struct., 32, 2547-2570 (1995).

7. T. Belytschko and M. Tabbara, "Dynamic fracture using element-free Galerkin methods," Int. J. Numer. Meth. Eng., 39, 923-938 (1996).

8. G. H. Shi and R. E. Goodman, "Discontinuous deformation analysis," in: Proc. 25th U.S. Symp. on Rock Mechanics, Paper 25-27, University of California (1984).

9. G. H. Shi and R. E. Goodman, "Generalization of two-dimensional discontinuous deformation analysis for forward modelling," Int. J. Numer. Anal. Meth., 13, 359-380 (1989).

10. R. J. Tsay, Y. J. Chiou, and W. L. Chuang, "Crack growth prediction by manifold method," J. Eng. Mech., 125, 884-890 (1999).

11. Y. J. Chiou, Y. M. Lee, and R. J. Tsay, "Mixed mode fracture propagation by manifold method," Int. J. Fract., 114, 327-347 (2002).

12. T. Belytschko and T. Black, "Elastic crack growth in finite elements with minimal remeshing," Int. J. Numer. Meth. Eng., 45, 601-620 (1999). 
13. N. Moes, J. Dolbow, and T. Belytschko, "A finite element method for crack growth without remeshing," Int. J. Numer. Meth. Eng., 46, 131-150 (1999).

14. T. Strouboulis, I. Babuska, and K. Copps, "The design and analysis of the generalized finite element method," Comput. Meth. Appl. Mech. Eng., 181, 43-69 (2000).

15. T. Strouboulis, K. Copps, and I. Babuska, "The generalized finite element method, An example of its implementation and illustration of its performance," Int. J. Numer. Meth. Eng., 47, 1401-1417 (2000).

16. P. O. Bouchard, F. Bay, and Y. Chastel, "Numerical modelling of crack propagation: Automatic remeshing and comparison of different criteria," Comput. Meth.. Appl. Mech. Eng., 192, 3887-3908 (2003).

17. D. Bremberg and G. Dhondt, "Automatic crack-insertion for arbitrary crack growth," Eng. Fract. Mech., 75, 404-416 (2008).

18. M. S. Shephard, “Automatic crack propagation tracking," Comput. Struct., 20, 211223 (1985).

19. M. Souiyah, A. Muchtar, A. Alshoaibi, and A.K. Ariffin, "Finite element analysis of the crack propagation for solid materials," Amer. J. Appl. Sci., 6, Issue 7, 1396-1405 (2009).

20. Y. Q. Chen, X. P. Zheng, and Z. H. Yao, "Numerical simulation of failure processes in 3D heterogeneous brittle material," Acta Mech. Sinica, 34, 351-361 (2002).

21. R. J. Nuismer, "An energy release rate criterion for mixed mode fracture," Int. J. Fracture, 11, 245-250 (1975).

22. N. E. Dowling, K. S. Prasad, and R. Narayanasamy, "Mechanical behavior of materials: Engineering methods for deformation, fracture, and fatigue," in: Yielding and Fracture under Combined Stresses, 3rd edition, Ch. 7, Pearson Prentice Hall, Washington (2009), pp. 241-243.

23. G. C. Sih, "Strain-energy-density factor applied to mixed mode crack problems," Int. J. Fracture, 10, 305-321 (1974).

24. J. R. Rice, "A path independent integral and the approximate analysis of strain concentration by notches and cracks," J. Appl. Mech., 35, 379-386 (1968).

25. M. F. Kanninen, "An augmented double cantilever beam model for studying crack propagation and arrest," Int. J. Fracture, 9, 83-92 (1973).

26. D. Xie and S. B. Biggers, Jr., "Progressive crack growth analysis using interface element based on the virtual crack closure technique," Finite Elem. Anal. Des., 42, 977-984 (2006).

27. H. H. Zhang, L. X. Li, X. M. An, and G. W. Ma, "Numerical analysis of 2 D crack propagation problems using the numerical manifold method," Eng. Anal. Bound. Elem., 34, 41-50 (2010).

28. Z. D. Qian, Z. Li, and C. H. Chen, "Fracture criterion for mode I crack of epoxy asphalt concrete paving course of steel deck bridge pavement," China J. Highway Transport, 21, 33-38 (2008).

29. Y. Sumi, "Fatigue crack propagation and computational remaining life assessment of ship structures," J. Mar. Sci. Technol., 3, 102-112 (1998).

30. M. Fleming, Y. A. Chu, B. Moran, and T. Belytschko, "Enriched element-free galerkin methods for crack tip fields," Int. J. Numer. Meth. Eng., 40, 1483-1504 (1997). 